\title{
Reconciling global sustainability targets and local action for food production and climate change mitigation
}

\author{
Juliana D.B. Gil ${ }^{\mathrm{a}}$, Vassilis Daioglou ${ }^{\mathrm{b}, \mathrm{c}, *}$, Martin van Ittersum ${ }^{\mathrm{a}}$, Pytrik Reidsma ${ }^{\mathrm{a}}$, \\ Jonathan C. Doelman ${ }^{\mathrm{b}}$, Corina E. van Middelaar ${ }^{\mathrm{d}}$, Detlef P. van Vuuren ${ }^{\mathrm{b}, \mathrm{c}}$ \\ ${ }^{a}$ Plant Production Systems, Wageningen University, P.O. Box 430, 6700 AK Wageningen, the Netherlands \\ ${ }^{\mathrm{b}}$ PBL Netherlands Environmental Assessment Agency, 2500 GH The Hague, the Netherlands \\ ${ }^{\mathrm{c}}$ Copernicus Institute of Sustainable Development, Utrecht University, 3584 CS Utrecht, the Netherlands \\ ${ }^{\mathrm{d}}$ Animal Production Systems, Wageningen University, P.O. Box 338, 6700 AH Wageningen, the Netherlands
}

\section{A R T I C L E I N F O}

\section{Keywords:}

Sustainable Development Goals

Cross-scale analysis

Trade-offs

Scenario analysis

Agriculture

\begin{abstract}
A B S T R A C T
The Sustainable Development Goals (SDGs) imply country-led implementation. Yet, their achievement depends on sustainability targets compatible across different sectors and scales. Our study examines how the GHG emission intensity of agriculture (EIA) should evolve globally, regionally (Western Europe) and nationally (The Netherlands) under different socioeconomic pathways, so that two major aims of SDGs 2 and 13 (i.e. sufficient food production and climate change mitigation) are achieved simultaneously. Results show that, by 2050, relative to 2010 values, EIA should decrease at all three levels when measured on a product basis (GHG emissions per ton dry matter) and on a land basis (GHG emissions per ha). This indicates that, globally, agriculture should be intensified per unit area, while in Western Europe and even more so in the Netherlands additional emission reductions require increased production efficiency and lower production volumes. Projected reductions in methane and nitrous oxide emissions from enteric fermentation, manure management and fertilizer application in Dutch agriculture are much higher than what would be achieved through the extrapolation of current trends. Given the high costs of increasing production efficiency further, our analysis indicates the need for significantly more ambitious policy targets and systemic changes, including reduced consumption of animal-sourced food. Besides shedding light on the interaction between climate and agricultural strategies, our analysis illustrates the application of cross-scale thinking in the operationalization of the SDG agenda and underscores the need for concerted action amongst countries.
\end{abstract}

\section{Introduction}

The 17 Sustainable Development Goals (SDGs) launched in 2015 by the United Nations aim at "ending poverty, protecting the planet and ensuring prosperity for all" (UN, 2015). The SDGs were designed according to the principle of country-led implementation, through which local diversity and context-specificities should be considered. At the same time, sustainability actions taken locally must, on aggregate, be consistent with planetary boundaries and global ambitions such as reducing poverty worldwide (Rockström et al., 2009). The pursuit of the SDG agenda thus relies on the simultaneous and integrated achievement of targets at the national, regional and global levels.

Policies to implement the SDGs also need to take account of the interactions between the SDGs. These interactions have been recently highlighted by several studies (Nilsson et al., 2016; van Vuuren et al., 2015; Pradhan et al., 2017). Here, we focus mostly on the interactions between SDGs related to climate change and food systems. Agriculture is directly responsible for around $13 \%$ of global greenhouse gas (GHG) emissions (Stocker et al., 2013) and constitutes the main driver behind land-use emissions. Despite uncertainties as to its exact contribution to climate change mitigation (Wollenberg et al., 2016), the sector is paramount to reach the goals of the Paris Climate Agreement (which imply net zero GHG emissions after 2050), especially given its interaction with land-based mitigation strategies (Popp et al., 2017) and the possible need for negative emissions (Allen et al., 2018). Moreover, there will be a clear need to increase food production globally over the

\footnotetext{
* Corresponding author.

E-mail addresses: juliana.diasbernardesgil@wur.nl (J.D.B. Gil), vassilis.daioglou@pbl.nl (V. Daioglou), martin.vanittersum@wur.nl (M. van Ittersum), pytrik.reidsma@wur.nl (P. Reidsma), jonathan.doelman@pbl.nl (J.C. Doelman), corina.vanmiddelaar@wur.nl (C.E. van Middelaar), detlef.vanvuuren@pbl.nl (D.P. van Vuuren).
} 
same period in order to feed 9-10 billion people in 2050 (Godfray et al., 2010), despite possibly detrimental impacts of climate change. The future development of agriculture is hugely important for climate security (SDG 13), food security (SDG 2), economic prosperity of rich and poor regions alike (SDG 1) and terrestrial and marine biodiversity (SDGs 14 and 15).

While regional trajectories of agricultural emissions are crucial for climate change mitigation, much uncertainty exists as to the various development pathways that society may undertake. The unpredictability of climate change itself, as well as population dynamics, market fluctuations, trade flows and varying governance levels are some of the factors that compound such uncertainty, ultimately rendering scenario analysis valuable. In the case of global sustainability targets like climate change mitigation, additional complexity arises from the issue of effortsharing. Defining the level of responsibility of each world region - so that they achieve an emission intensity of agriculture (EIA) compatible with global climate change mitigation targets - involves ethical, historical, economic and development-related factors.

To date, most of the research on SDGs using integrated assessment models (IAMs) has focused on the analysis of potential synergies and trade-offs between SDGs globally (Rao et al., 2016; Obersteiner et al., 2016; van Vuuren et al., 2015). At this scale, IAMs are appropriate tools to account for the long-term interactions between human and natural systems. On the other hand, IAMs' high level of aggregation in terms of technological, spatial and temporal scales and relatively coarse global databases pose limits to the derivation of local policy recommendations. Several sectoral studies have focused on specific aspects of the SDG agenda at the more local scale such as population dynamics (Abel et al., 2016) and agriculture (Kanter et al., 2016). While most of them propose actions suited to different contexts, also their scalability is disputed since this is done irrespective of the links between regions and sectors. Despite the importance of bringing these efforts together for policy and research, few attempts have been made to check for consistency between results obtained at different scales or to elucidate their interdependence. Concerning agriculture, more specifically, a knowledge gap exists as to whether GHG emission trends observed in different countries are consistent with emission reduction requirements estimated at the regional and global scales (Palazzo et al., 2017; Vervoort et al., 2014).

This study shows what different climate change mitigation pathways entail for agricultural emissions at global and regional levels, and how downscaled country-specific estimates of agricultural emissions compare with current GHG emission trends and perspective for local action. All the pathways imply the production of enough food to feed the world population as well as the achievement of the climate change mitigation targets set forth by the Paris Agreement.

To illustrate the translation of global targets into local action, while also exploring the role of developed countries towards the SDGs, we select the Netherlands as a case study. With intensely managed farms and high per capita levels of animal-based protein consumption, the country plays a key role in the global food system as the second largest exporter of agricultural products and a net importer of feed concentrates (CBS, 2016). As such, it offers insights into the kinds of changes needed for other high-intensity countries to meet global climate change targets. More broadly, the use of a case study allows us to derive lessons relevant to the operationalization of SDGs, which invariably requires the reconciliation of sustainability targets across sectors and scales.

\section{Methods}

To analyse what different climate mitigation pathways entail for agricultural emissions at global and regional levels, and how downscaled country-specific projections of agricultural emissions compare with current emission trends, we adopt the GHG Emission Intensity of Agriculture (EIA) as a key performance indicator. EIA is measured for each region both in terms of total agricultural produce (EIA $\left.A_{D M}\right)$ and total farmland (EIA $\mathrm{Ha}_{\mathrm{a}}$ ), as further detailed in Section 2.3. Instead of presenting results for specific crops as in previous studies (Smith et al., 2016), we present results for agriculture as a whole, thereby allowing for flexibility concerning how EIA reductions are achieved at the local level (including product substitution for the best nutritional outcome possible).

Our study has three main parts. In the first part (Section 3.1) we use the result of an integrated assessment model to estimate the EIA of 26 world regions under different scenarios, so that climate change mitigation and sufficient food production are both secured by 2050 . We assess how EIA is projected to change across these world regions based on the lowest cost approach to mitigate climate change. In the second part (Section 3.2) we use the EIA curves obtained for the "Western Europe" region (WEU) under all four scenarios to derive a set of EIA curves for the Netherlands. The downscaling is done according to three different methods: (i) the Dutch share of WEU's production and GHG emissions in 2015 remains the same throughout the study's timeframe; (ii) the 2005-2015 trend of the Dutch share of WEU's production and GHG emissions is extrapolated until 2050; and (iii) the Dutch agricultural emissions reduce in line with EU policies on effort sharing. In the third part (Section 3.3) we compare past and current trends of GHG emissions in Dutch agriculture with downscaled results from the second part.

\subsection{Model framework}

IMAGE (Stehfest et al., 2014) is a dynamic integrated assessment modelling framework of interacting human and natural systems. As such, it is a useful tool to project and analyse global changes, particularly concerning transitions regarding the use of energy, land, water and other resources over the long run (up to the year 2100). While IMAGE models 26 world regions (the region classification map is available at http://models.pbl.nl/image/index.php/Region classification_map), land use, land cover and associated biophysical processes are treated at a $5 \times 5$ or $30 \times 30$ arcminute-resolution. The core model of IMAGE consists of the MAGNET agricultural economy general equilibrium model, the TIMER energy system simulation model, and the IMAGE-LPJmL model (which covers land allocation as well as carbon, water, and crop and vegetation dynamics).

\subsubsection{Agricultural economics}

In IMAGE, projected development of the agricultural economy is calculated using the agroeconomic model MAGNET (Woltjer et al., 2014). MAGNET is a computable general equilibrium model (CGE) connected via a soft link to the core model of IMAGE. MAGNET is an extended version of the GTAP model (Hertel, 1997), which is a multiregional, static, applied CGE. In addition, MAGNET includes international and EU agricultural policies, such as production quota and export/import tariffs (Helming et al., 2010).

Supply and demand: In MAGNET, demand for agricultural products is calculated based on changes in income, income elasticities, preference shift, price elasticities, cross-price elasticities, and the commodity prices arising from changes in the supply side. Demand and supply are balanced via prices to reach equilibrium. Income elasticities for agricultural commodities are consistent with FAO estimates (Britz, 2003) and dynamically depend on purchasing power parity-corrected GDP per capita. The supply of all commodities is modelled by an input-output structure that explicitly links the production of goods and services for final consumption via different processing stages back to primary products (crop and livestock products) and resources. At each production level, input of labour, capital and intermediate inputs or resources (e.g. land) can be substituted for one another according to changes in their relative prices.

Regional aggregation and trade: MAGNET calculations are made at the level of 129 regions, aggregated to 26 regions when linked with 
IMAGE. Like other CGE models, MAGNET assumes that products traded internationally are differentiated according to their country of origin; it follows that domestic and foreign products are imperfect substitutes.

Land use: MAGNET includes a dynamic land supply function (van Meijl et al., 2006) that accounts for the suitability and availability of land for agricultural use, based on information from IMAGE. A nested land use structure accounts for the differences in substitutability of the various types of land use.

Land supply: MAGNET calculates land supply as a function of land used in agriculture and land prices. Total land supply includes all land that is potentially available for agriculture, where crop production is possible under soil and climate conditions, and where no other restrictions apply such as urban or protected area designations. In IMAGE, land supply in each region is obtained from potential crop productivity and land availability on a $5 \times 5$ arcminute-resolution. The supply curve depends on total land supply, current agricultural area, current land price, and estimated price elasticity of land supply in the starting year (Mandryk et al., 2015). In regions with a large reserve of suitable agricultural land, such as Sub-Saharan Africa and some regions in South America, the price elasticity of land supply is higher, with expansion of agricultural land occurring at smaller price changes. Land supply can be restricted in IMAGE and MAGNET. The exclusion of some areas from the land supply curve leads to lower elasticities, less land-use change and higher prices (Overmars et al., 2014).

Agricultural intensification: Biophysical yield effects due to climate and area changes are calculated by the dynamic global vegetation model LPJmL (Bondeau et al., 2007) and communicated to MAGNET. Crop and pasture yields in MAGNET may change as a result of four processes: (i) autonomous technological change (external scenario assumption); (ii) substitution of production factors (endogenous); (iii) climate change (from IMAGE); and (iv) changes in agricultural area affecting crop yields (e.g. decreasing yields due to expansion into less suitable regions from IMAGE).

\subsubsection{Land-use allocation}

IMAGE distinguishes extensive grassland, agricultural and nonagricultural grid cells, and within agricultural land areas fractions of grass, seven rain-fed and seven irrigated crop types, and bioenergy crops. These include temperate cereals, rice, maize, tropical cereals, roots and tubers, pulses and oil crops (both rain-fed and irrigated); grass, sugar cane and maize for bioenergy; and woody and non-woody bioenergy.

Cropland abandonment and expansion are based on productivity levels of each location. Expansion allocation, in particular, is determined through an algorithm with four drivers: potential crop yields, accessibility (Nelson, 2008), population density (Klein Goldewijk et al., 2010), and terrain slope index (IIASA, 2012). Next to land use allocation, IMAGE land management models the livestock production for five classes (beef, dairy cattle, pigs, poultry, sheep and goats) for 26 regions. Ruminants can be produced in intensive or extensive systems, taking into account large variations between regions in feed composition, feed efficiency, genetic animal productivity and age at slaughter (Bouwman et al., 2005). The livestock production module determines the amount of feed crops and grass required to fulfil demand for animal production as calculated by MAGNET. Expansion or abandonment of grazing land depends on demand for grass and follows the same allocation procedure as cropland.

\subsubsection{Model calibration and validation}

For the purposes of calibration, IMAGE reproduces history from 1971 onwards. The historical land use in IMAGE is consistent with FAO statistics. Historical rates of regional crop yield changes, efficiency of livestock systems and fertilizer application are calibrated to FAOSTAT data, while the FAO Agricultural Outlook (Alexandratos and Bruinsma, 2012) aids the calibration of future projections. The energy module of IMAGE (TIMER) is calibrated according to the International
Energy Agency (IEA, 1970-2012) while land use emission factors are based on the EDGAR database (JRC, 2011).

As for validation, modelling consortia (e.g. IAMC, AgMIP) conducted several model comparison exercises in the past years highlighting differences concerning projected land use, agricultural production, crop yields, carbon and nutrient cycles and response to climate shocks (Popp et al., 2017; Lampe et al., 2014; Nelson et al., 2014; Schleussner et al., 2018). These differences affect each models' mitigation potential of the agricultural sector. When it comes to $\mathrm{CH}_{4}$ and $\mathrm{N}_{2} \mathrm{O}$ from agriculture, IMAGE is in line with emission projections from other integrated assessment models under both SSP1 and SSP2 (Popp et al., 2017; van Meijl et al., 2018). Moreover, IMAGE is the marker for simulations under SSP1, which other models try to emulate (van Vuuren et al., 2017b), while the analysis of different scenarios allows us to explore uncertainty in some parameters.

\subsubsection{Carbon tax}

In IMAGE, a price on greenhouse gas emissions ('carbon tax') is introduced to meet the climate targets. This price stimulates changes in production and consumption patterns related to the energy system, and production emissions in the land system, to reduce all gaseous emissions covered by the Kyoto Protocol (i.e. $\mathrm{CO}_{2}, \mathrm{CH}_{4}, \mathrm{~N}_{2} \mathrm{O}$ and others). It should be noted that the tax is not intended as a specific policy instrument, but rather constitutes a generic mechanism - used in most IAMs - to simulate the effort involved in abating emissions. As a result, changes in the model with marginal cost below the level of the tax will be introduced. In IMAGE, the climate policy model FAIR-SimCAP is used to determine global emission pathways with a long-term climate target (den Elzen et al., 2008). The FAIR-SimCAP model receives input on mitigation costs from the various components of IMAGE. This includes information on $\mathrm{CO}_{2}$ emission reduction in energy, but also action to reduce non- $\mathrm{CO}_{2}$ emissions in all sectors. The ambition level of REDD and reforestation of degraded forest areas is roughly calibrated to the carbon price (Kindermann et al., 2008).

\subsection{Scenarios}

EIA simulations are done under two storylines, so-called Shared Socioeconomic Pathways (SSPs). SSPs consist of development trajectories representative of a range of possible socioeconomic conditions for the future. As such, they provide a framework for the assessment of sustainability pathways across storylines and associated challenges for climate mitigation and adaptation (Riahi et al., 2017; Van Vuuren et al., 2014; O'Neill et al., 2014; Ebi et al., 2014). In our analysis, the two SSP baselines able to meet climate mitigation targets from the Paris Climate Agreement according to IMAGE projections were considered:

- SSP1 ("Sustainability") - Describes a future pathway with low challenges for adaptation and mitigation, where the world shifts gradually towards a state of greater sustainability. Under climate change mitigation targets, land use is strongly regulated (tropical deforestation falls significantly); crop yields rapidly increase in lowand medium-income regions; animal calorie intake is decoupled from household income (which, in face of a higher income, implies a lower increase of animal protein intake compared to historical trends); food waste is reduced; international food markets are wellconnected; and international cooperation on climate change mitigation starts in 2020 with integral participation of the land use sector.

- SSP2 ("Middle-of-the-road") - Describes medium challenges for adaptation and mitigation and is intended to represent a future in which development trends are not extreme in any of the dimensions, but rather follow middle-of-the-road pathways. In the climate change mitigation targets, similar constraints as those in SSP1 are placed but with lower ambitions, i.e. the decline in deforestation rates happens at a lower rate; yield increase through technological 
change takes place at a medium pace; dietary patterns follow the trends of meat consumption historically associated with increasing income; a semi-open globalized economy prevails; and international cooperation for climate change mitigation is delayed, with partial participation of the land use sector.

Regional crop yield changes assume that $50 \%$ of the improvement is autonomous while the other $50 \%$ is price-driven. The autonomous improvement of SSP1 is higher than that of SSP2 thanks to the former's higher GDP projections. Still in SSP1, fertilizer efficiency improvement is $20 \%$ higher than SSP2, except for in Sub-Saharan Africa where application increases due to the occurrence of nutrient mining (Lassaletta et al., 2014). Likewise, livestock system efficiencies are assumed to increase faster in SSP1 than in SSP2 due to continued economic growth and a subsequent increase in demand for animal source food (less efficient regions experience 50\% convergence with the most efficient regions). For further details on the implementation of the SSPs in IMAGE, see Appendix (Table S2).

All results are presented for both SSPs and associated climate change mitigation projections consistent with the achievement of the $1.5{ }^{\circ} \mathrm{C}$ and $2{ }^{\circ} \mathrm{C}$ climate targets by 2100 (Van Vuuren et al., 2011; Riahi et al., 2017). Relevant climate policies (in the form of a carbon tax and land protection strategies) ensure the necessary mitigation level, with emission reduction taking place in both the energy and the land use systems (see Appendix - Fig. S1). The four scenarios resulting from the combination of storylines and climate targets are henceforth called SSP1-1.5C, SSP2-1.5C, SSP1-2C and SSP2-2C.

\subsection{GHG estimates}

IMAGE calculates agricultural emissions based on the level of activity of different processes (for emission factors, see Doelman et al., 2018). For land use change emissions, the LPJml model includes carbon stock accounting on a $30 \times 30$ arcminute-resolution. For the energy system, emission factors are assigned to primary energy carriers demanded. The options for GHG emissions abatement included in IMAGE - and used for the projections of climate change mitigation scenarios are explained in detailed in the Appendix - part 7.

EIA is calculated as total emissions divided by total agricultural production $\left(\mathrm{EIA}_{\mathrm{DM}}\right)$ and total utilized agricultural area $\left(\mathrm{EIA}_{\mathrm{Ha}}\right)$. "Total agricultural production (Mt DM/year)" includes energy-crops, other crops, and livestock. "Total emissions (ton $\mathrm{CO}_{2} \mathrm{eq} / \mathrm{year}$ )" include the major GHG included in the Kyoto Protocol: $\mathrm{CH}_{4}$ from agricultural waste burning, enteric fermentation, manure, and rice; and $\mathrm{N}_{2} \mathrm{O}$ from manure management, managed soils, biomass burning, and land.

\section{Results}

\subsection{Modelled EIA projections at the global and regional levels}

\subsubsection{World}

Climate change mitigation requires actions in the land and energy systems (Figure S1). In SSP1-2C, a substantial share of the mitigation is achieved through land-related measures, particularly lower methane $\left(\mathrm{CH}_{4}\right)$ emissions and afforestation. Contrastingly, in SSP2-2C, higher food demand and lower technological improvement lead to increased mitigation efforts from the energy system (Fig. S1) and an overall higher carbon tax (see Discussion and Appendix - Fig. S3). In both SSPs, emission reduction comes primarily from decrease in $\mathrm{CO}_{2}$ emissions.

Global agricultural production increases substantially until 2050 under both SSPs due to growing population and affluence (Fig. 1). By 2050, the production of food and feed goes up by $61 \%$ in SSP1 (under both climate targets) and 72\% and 73\% in SSP2-1.5C and SSP2-2C, respectively. Livestock production is projected to go up by $50 \%$ in SPP1 and $67 \%$ in SSP2 irrespective of the climate target considered in each case. The increase in the production of energy crops is much higher, particularly in the second half of the century, as a strategy to reduce GHG emissions in the energy system and meet mitigation targets. This happens through so-called negative emissions via the use of bioenergy combined with carbon capture and storage (Rose et al., 2014; Bauer et al., 2018; Clarke et al., 2014). In IMAGE, the projected bioenergy use is primarily based on biofuels from lignocellulosic feedstocks and electricity or hydrogen production combined with carbon capture and storage (for details see Daioglou et al., 2019). By 2050, Latin America (LAM) and Sub-Saharan Africa (SSA) increase their share in global food production (Fig. S2) due to a projected increase in food demand, as well as currently high yield gaps and local land abundance. This expansion takes place in savannahs (tropical forests are protected in climate change mitigation scenarios) which may have diverse effects on biodiversity and other environmental indicators (Doelman et al., 2018).

By 2050, global agricultural GHG emissions are projected to be reduced under all scenarios except for SSP2-2C, where it remains largely unchanged (Fig. 1, middle column) (van Vuuren et al., 2017b; Doelman et al., 2018). While most of the reduction in net GHG emissions under SSP1-2C happens until 2050, in SSP2-2C the greater pressure for food production due to higher population growth causes most of the emission reduction to take place in the second half of the century. Until $2050, \mathrm{~N}_{2} \mathrm{O}$ emissions are fairly constant in SSP1 and increase by $30 \%$ in SSP2 with food production roughly doubling. Besides the limited potential to reduce $\mathrm{N}_{2} \mathrm{O}$ emissions (Gernaat et al., 2015), this is partly because measures to reduce $\mathrm{N}_{2} \mathrm{O}$ emissions are more expensive than the carbon tax (Fig. S3). Alternatively, reductions in meat consumption (and thus feed production) would allow for a decrease in $\mathrm{N}_{2} \mathrm{O}$ emissions (as well as $\mathrm{CO}_{2}$ and $\mathrm{CH}_{4}$ emissions through a reduction in land use change and number of animals) (van Vuuren et al., 2018).

EIA can be measured per unit output $\left(\mathrm{tCO}_{2} \mathrm{e}\right.$ tonDM $\left.{ }^{-1}\right)$ or land use $\left(\mathrm{tCO}_{2} \mathrm{e} \mathrm{ha}^{-1}\right)$. These are presented as EIA $\mathrm{DM}_{\text {and EIA }}$, respectively. By 2050 , projected decreases in the world's EIA $\mathrm{Ha}_{\text {}}$ (i.e. $12 \%$ in SSP1-2C and approximately constant in SSP2-2C) are much smaller than decreases in the world's EIA $\mathrm{DM}_{\mathrm{DM}}$ (i.e. 52\% in SSP1-2C and 56\% in SSP2-2C) since most of the global agricultural production increase is to be achieved through intensification as opposed to area expansion (Fig. 1).

\subsubsection{Western Europe}

Agricultural production is projected to increase in WEU, though at a lower rate than globally. The share of WEU in global food production is projected to fall from $9 \%$ in 2010 to approximately $5 \%$ in all scenarios by 2050 , despite a projected overall growth in WEU's total agricultural production, particularly in SSP2. The projected increase in food production is higher in SSP2-1.5C (58\%) than in SSP2-2C (21\%) because expansion in LAM and AFR is constrained, leading to more production in Europe. At the same time, agricultural land is projected to contract in the WEU under all scenarios, especially in the case of grasslands due to a shift towards livestock with larger shares of feed crops relative to grass. The only exception is SSP2-1.5C, under which agricultural land increases slightly (largely due to bioenergy production).

Over the same period, WEU's share of the world's agricultural emissions (i.e. 8\% in 2010) approximately halves under both SSPs. In fact, contrary to most world regions, agricultural emissions in Western Europe are projected to start falling early on under both SSPs (Fig. S4). From 2010 to 2050, WEU's agricultural emissions under the $2{ }^{\circ} \mathrm{C}$ climate target fall by $49 \%$ in SSP1 and $36 \%$ in SSP2. Under the $1.5{ }^{\circ} \mathrm{C}$ climate target, they fall by $52 \%$ and $34 \%$ in SSP1 and SSP2, respectively.

EIA trends at the global level imply different EIA trajectories across

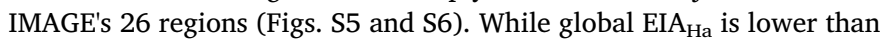
WEU's EIA $_{\mathrm{Ha}}$, global EIA $\mathrm{DM}_{\mathrm{DM}}$ is higher than WEU's EIA $\mathrm{DM}_{\mathrm{B}}$, reflecting the region's higher yields. Under SSP1 and SSP2, both in the world and Western Europe, the projected relative decline in EIA $A_{D M}$ is greater than that of EIA $\mathrm{Ha}_{\text {. The decline in EIA }}$ is is due to a combination of increased agricultural production and decreased emissions (with the former playing the most important role in SSP2-2C), while the decline in $\mathrm{EIA}_{\mathrm{Ha}}$ 

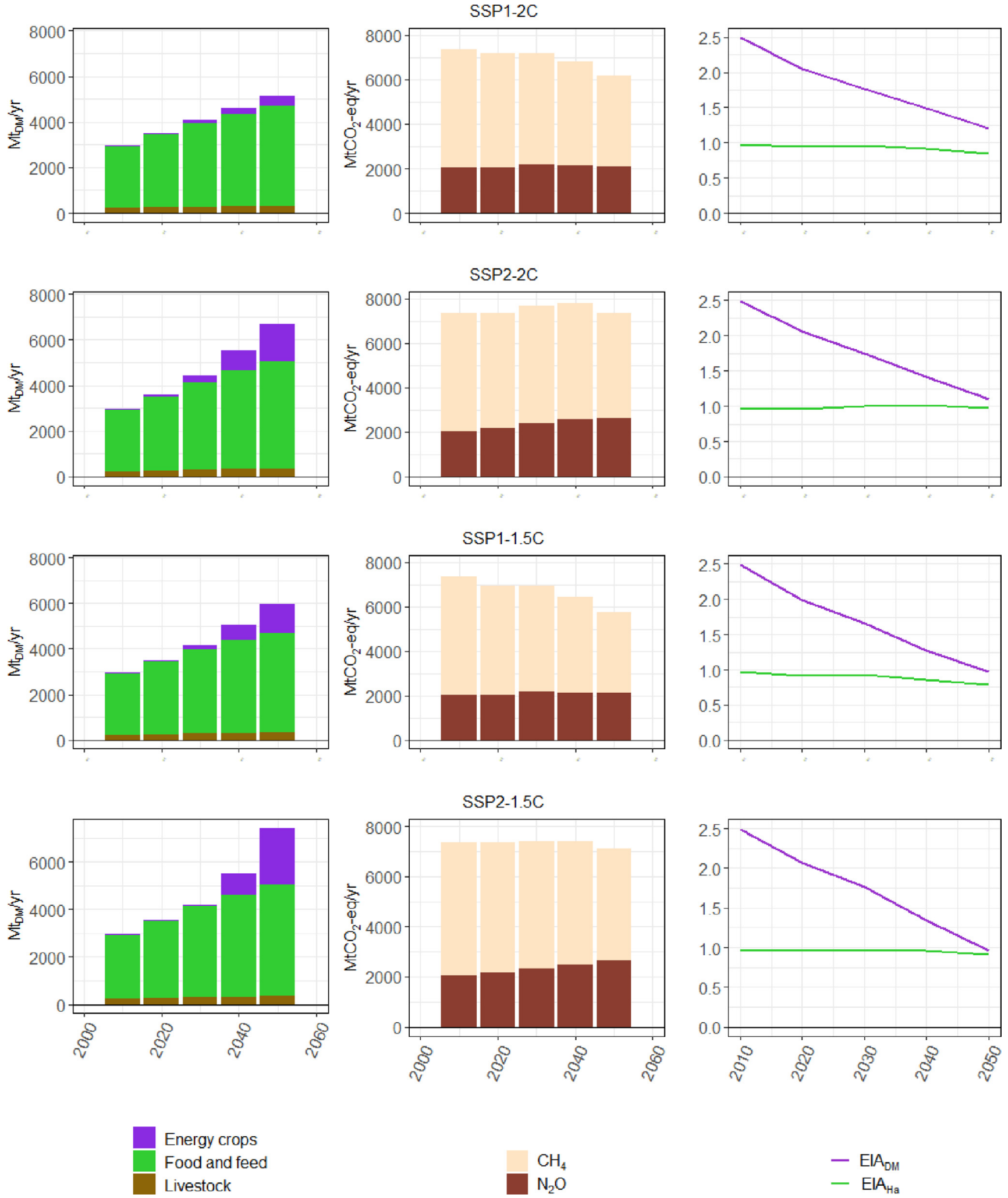

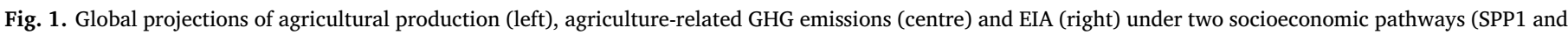

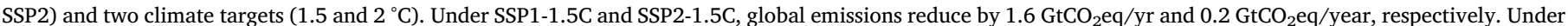
SSP1-2C and SSP2-2C, global emissions decrease by $1.1 \mathrm{GtCO}_{2} \mathrm{eq} /$ year and increase by $0.02 \mathrm{GtCO}_{2} \mathrm{eq} /$ year, respectively.

is driven by decreased emissions rather than increased acreage under both SSPs.

\subsection{Modelled EIA projections downscaled for the Netherlands}

Given the uncertainties about how agricultural production and emissions will evolve in the future, we obtained EIA projections for the Netherlands using three different downscaling methods (Fig. 2). In 

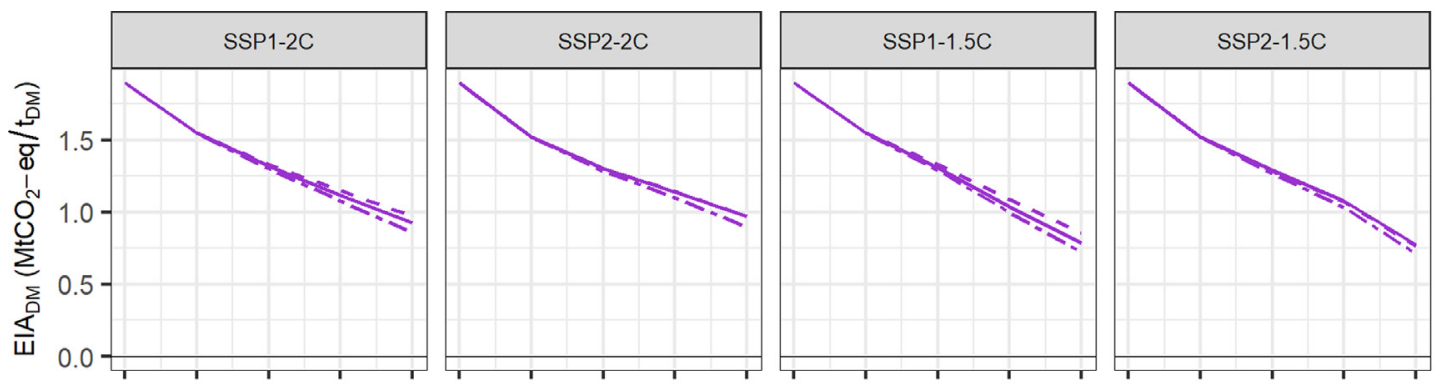

Downscaling Method:
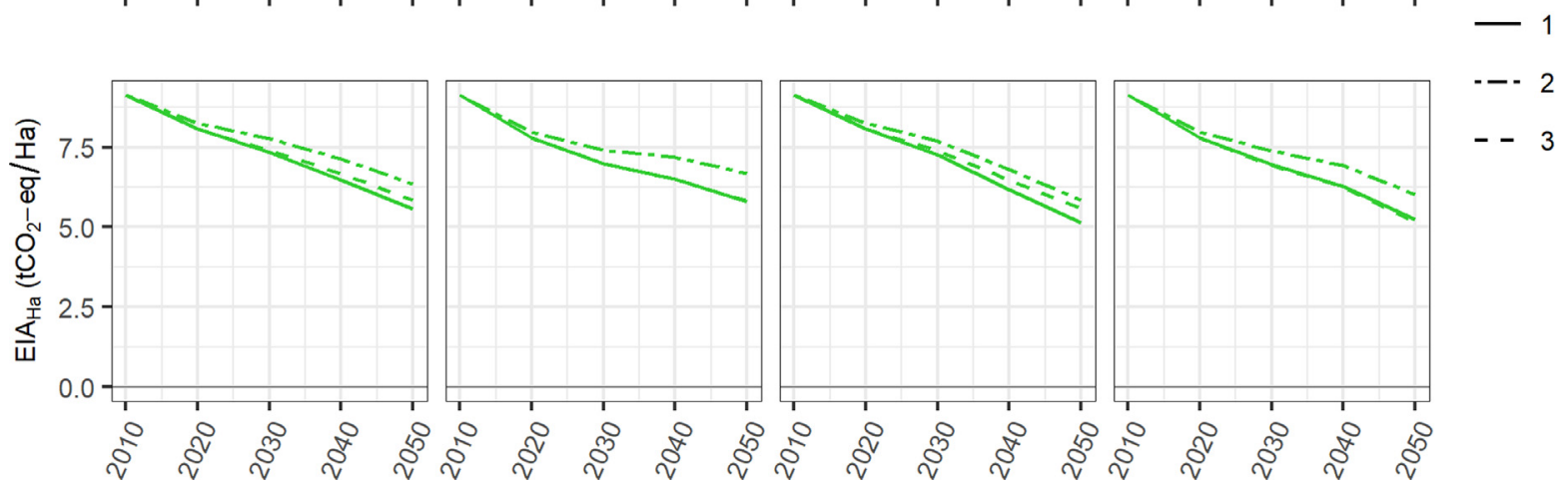

Fig. 2. Projections for $\mathrm{EIA}_{\mathrm{DM}}$ (top row) and EIA $\mathrm{Ha}_{\text {a }}$ (bottom row) for the Netherlands across all scenarios, according to three downscaling methods.

Method 1, we simply extrapolated current (i.e. 2015) Dutch shares of food production and GHG emissions within WEU, calibrated according to FAO statistics (FAOSTAT, 2017) and the latest Dutch National GHG Inventory Report (Coenen, 2017). Method 2 is the same as Method 1 except that, instead of current shares, we extrapolated a 10-year trend (i.e. 2005-2015) of the Dutch share of GHG emissions and agricultural production within WEU. Finally, Method 3 is based on the EU Effort Sharing Decision (EU-Commission, 2009), which establishes that the contribution of each EU country towards the EU's total emission must be proportional to that country's share of the EU's gross domestic product per capita. The less wealthy a country, the less ambitious its targets. By applying this rule and assuming that the Dutch share of WEU's agriculture production remains the same, we determined what the Dutch agricultural GHG emissions should be by 2050 and, thus, EIA trends in the Netherlands.

Total agricultural GHG emissions in the Netherlands are projected to fall by $34-51 \%$ (i.e. 8-12 MtonCO $_{2}$ eq) from 2010 to 2050 across all scenarios and downscaling methods. The three downscaling methods point at consistent EIA reduction ranges, with the $1.5^{\circ} \mathrm{C}$ target implying a greater reduction of about 5-10 percentage points in both EIA $_{\mathrm{Ha}}$ and EIA $_{D M}$ than that shown under the $2{ }^{\circ} \mathrm{C}$ target (Fig. 2). Both EIA ${ }_{\mathrm{Ha}}$ and EIA $_{\mathrm{DM}}$ must reduce significantly (Table 1).

\subsection{Empirical EIA trends in Dutch agriculture}

Total GHG emissions in the Netherlands decreased by about $24 \%$ over 1990-2015, from 25.3 to $19.2 \mathrm{MtCO}_{2}$-eq (Coenen, 2017). The share of the Dutch emissions attributable to agriculture went from

Table 1

Reduction ranges needed to achieve the 1.5 and $2{ }^{\circ} \mathrm{C}$ climate mitigation targets under SSP1 and SSP2 in terms of EIA $\mathrm{DM}_{\mathrm{DM}}$, EIA $\mathrm{H}_{\mathrm{Ha}}$, methane and nitrous oxide for the Netherlands. Ranges indicate variations across all three downscaling methods applied. Values are expressed in \% and refer to the 2010-2050 period.

\begin{tabular}{lllll}
\hline & SSP1-1.5C & SSP2-1.5C & SSP1-2C & SSP2-2C \\
\hline EIA $_{\text {DM }}$ & $55-62$ & $59-62$ & $49-55$ & $49-53$ \\
EIA $_{\mathrm{Ha}}$ & $36-44$ & $34-43$ & $31-39$ & $27-37$ \\
$\mathrm{CH}_{4}$ & $47-52$ & $38-39$ & $48-50$ & $35-38$ \\
$\mathrm{~N}_{2} \mathrm{O}$ & $47-51$ & $33-37$ & $46-49$ & $34-38$ \\
\hline
\end{tabular}

$11.3 \%$ in 1990 to $9.8 \%$ in 2015 (excluding emissions related to land use and land-use change), however increasing trends for $\mathrm{N}_{2} \mathrm{O}$ and $\mathrm{CH}_{4}$ from agricultural processes were observed in recent years. Despite variations over time in the EIA values associated to dairy and crop production (Fig. 3), enteric fermentation, manure management and agricultural soils - particularly the use of organic and synthetic fertilizers - still constitute the main sources of direct GHG emissions in agriculture (representing 44\%, 23\% and 28\% of the sector's total emissions in 2015, respectively) (Table $\mathrm{S} 1$ ).

\subsubsection{Methane from enteric fermentation}

Cattle alone is responsible for $89.4 \%$ of the methane emissions related to enteric fermentation in the Netherlands (Coenen, 2017). The emissions are calculated based on the country's herd size multiplied by animal-specific emission factors (EF), accounting for age and ration. For IPCC reporting purposes, the Netherlands determines EFs for three categories of cattle, of which mature dairy cattle corresponds to the main share. Since 1990, the emission factor of dairy cattle has increased by $17 \%$ due to increased feed intake, while milk productivity increased even more (39\%), ultimately leading to lower EIA $_{\mathrm{DM}}$ related to enteric fermentation of $15 \%$ (Fig. 3a).

Numerous strategies have been proposed to reduce enteric methane emissions but reaching their widespread adoption and full effectiveness can be difficult. Dutch average yields are already among the highest in the world (about 90001 of milk per year per cow) (CBS, 2018), rendering further yield gains expensive. Besides, the increase in milk yield has come at the expense of health and fertility performance (Gerber et al., 2013). A production strategy focused on more lactations over a longer lifetime could help lower EIA $\mathrm{DM}_{\mathrm{D}}$ by reducing the number of replacement animals and increasing the overall productivity of the herd, especially when accompanied by reduced disease incidence (Mostert et al., 2018). Breeding for increased feed efficiency would also lower feed intake and subsequently reduce $\mathrm{EIA}_{\mathrm{DM}}$. So far, however, experimental data linking feed efficiency and methane has been inconclusive (Olijhoek et al., 2018) and direct breeding for reduced methane emissions appears difficult (de Haas et al., 2017).

In addition to breeding, feeding strategies have been shown to reduce enteric methane. Improving forage quality (i.e. digestibility) could effectively reduce $\mathrm{EIA}_{\mathrm{DM}}$ under certain conditions, for example 
a.

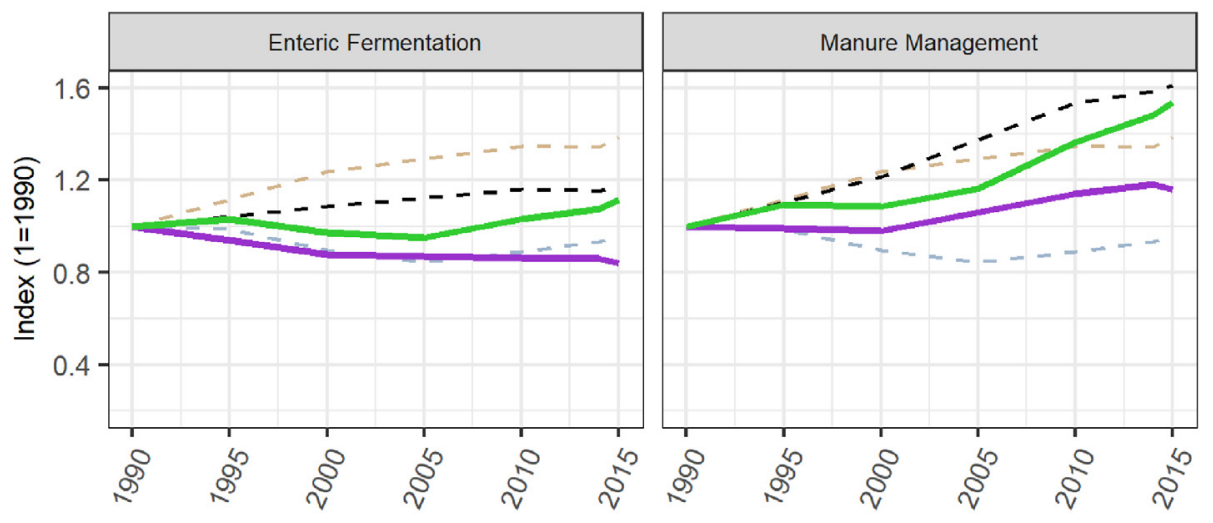

- $\operatorname{EIA}_{\mathrm{DM}}\left(\mathrm{kgCH}_{4} / \mathrm{kg}_{\text {Milk }}\right)$

- $\mathrm{EIA}_{\mathrm{Ha}}\left(\mathrm{kgCH}_{4} / \mathrm{ha}\right)$

- - Productivity $\left(\mathrm{kg}_{\text {Mik }} /\right.$ Animal/yr)

- - Stocking Rate (Animal/ha)

- - Emission Factor $\left(\mathrm{kgCH}_{4} /\right.$ Animal)

b.

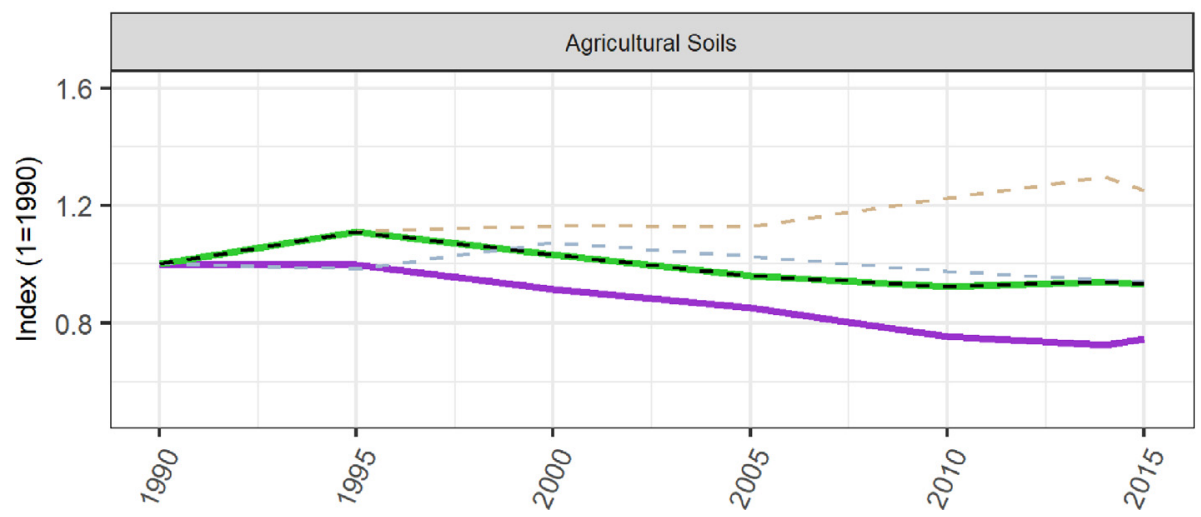

- $E I A_{D M}\left(\mathrm{kgN}_{2} \mathrm{O} / \mathrm{kg}_{\mathrm{Crop}}\right)$

- $E I A_{\mathrm{Ha}}\left(\mathrm{kgN}_{2} \mathrm{O} / \mathrm{ha}\right)$

- - Crop Yields (t/ha)

- - Cropland (ha)

- - Nitrogen Application (kgN/ha/yr)

Fig. 3. Past trends of EIA $\mathrm{Ha}_{\mathrm{a}}$ and EIA $\mathrm{DM}_{\mathrm{DM}}$ associated with the production of (a) dairy and (b) crops in the Netherlands from 1990 to 2015.

(Hristov et al., 2013). Ongoing research includes the use of anti-methanogenic algae (Machado et al., 2018). However, long-term effects of most feed supplements (such as fatty acids, dietary nitrate or tannins) are uncertain, especially when accounting for potential side-effects to animal health and productivity (Lee and Beauchemin, 2014). Increasing the maize-grass ratio in animal feed has been suggested as a methane reduction strategy but could imply food-feed competition or cause a shift from grass to cropland (often associated with soil carbon losses and subsequent $\mathrm{CO}_{2}$ emissions) (Van Middelaar et al., 2013; Van Middelaar et al., 2014). In addition, the Netherlands relies on the nonconversion of grasslands to comply with the country specific condition for derogation from the EU Nitrate Directive, according to which nitrogen application rates in grassland may exceed the limit of $170 \mathrm{~kg} / \mathrm{ha} /$ year imposed on other EU countries (Schröder and Neeteson, 2008). Feeding strategies to reduce enteric methane might increase GHG emissions from feed production, which should be considered when seeking overall net reduction in GHG.

\subsubsection{Methane from manure management}

Methane emissions related to manure management depend on the quantity and composition of manure, the management system employed (either liquid or solid, of which the first has higher emissions), as well as the time manure is stored for (the longer the time, the higher the emissions) (Van der Hoek and Van Schijndel, 2006). In the Netherlands, most of the methane from manure management is related to dairy cattle $(12 \%$ of the total agricultural methane emissions) (Coenen, 2017). The emission factor of dairy cattle has increased since 1990 due to greater confinement time and associated excretion rates (leading to higher $\mathrm{EIA}_{\mathrm{Ha}}$ and $\mathrm{EIA}_{\mathrm{DM}}$ ) (Fig. 3a, right panel). Contrastingly, the emission factor of swine has decreased by about $30 \%$ during the same period thanks to lower excretions, counteracting the increase in animal numbers while yields remained constant.

The mitigation potential in manure management in the Netherlands is uncertain. Some improvement could be achieved through technical measures that lower the storage time and temperature of manure, or the separation of the solid fraction and its application as fertilizer. Yet, trade-offs may require investments additional to the cost of technological implementation. Increasing grazing time, leading to lower methane emissions, would probably result in slightly lower milk yields and increased ammonia and nitrous oxide $\left(\mathrm{N}_{2} \mathrm{O}\right)$ emissions. Shifting animal feed from grass to maize is not attractive to farmers who dispose manure in grasslands, as explained above. Also, better timing of manure application to cropland could help avoid leakages but would also require longer storage times (Montes et al., 2013).

Biodigesters have high mitigation potential and can be implemented at the farm level or as centralised units where transportation needs are low (like in intensive agricultural zones such as Western Europe) (Kool et al., 2005). Despite growing investments (van Asselt et al., 2007), biodigesters are not always economically feasible given the combination of relatively low electricity prices in Europe, the lack of options for the utilization of heat generated during the combustion of biogas, as well as restrictions to the use of organic waste in the Netherlands. Finally, co-digestion with maize silage and other substrates that can be used as animal feed increases environmental impacts and should be avoided (De Vries et al., 2012).

\subsubsection{Nitrous oxide from agricultural soils}

Emissions from agricultural soils include several categories, of which the most important in the Netherlands is fertilizer application (Velthof and Losada, 2011) as soil organic matter content is largely 
Table 2

Agricultural (non- $\mathrm{CO}_{2}$ ) GHG emissions reduction for the European Union according to the EC 2050 Roadmap and IMAGE scenarios. All values are relative to 1990 emission levels.

\begin{tabular}{llll}
\hline Projection source & 2005 & 2030 & 2050 \\
\hline EC 2050 Roadmap (EU-28) & $-20 \%$ & -36 to $-37 \%$ & -42 to $-49 \%$ \\
IMAGE (WEU + Central Europe) & & -29 to $-36 \%$ & -41 to $-56 \%$ \\
\hline
\end{tabular}

constant (Reijneveld et al., 2009; van Grinsven et al., 2017). Since 1990 , the EIA $_{\mathrm{DM}}$ associated with synthetic fertilizer use in arable farming has decreased by approximately $25 \%$ due to higher crop yields and lower application rates (Prins et al., 2017). Higher nitrogen use efficiency, mainly through better application timing, allowed for less fertilizer at no yield loss.

Despite good average trends in NUE and nitrogen surplus, the use of synthetic fertilizer in the Netherlands has varied considerably in space and time (Prins et al., 2017). Variation also exists across farmers; some potato growers, for instance, must improve their NUE by almost $40 \%$ to reach an optimal level of 0.75 (Tenreiro, 2017). Although precision agriculture could increase NUE further for some crops without compromising yields (Silva et al., 2017), machinery costs have so far posed a barrier to adoption. The high levels of fertilizer application observed in the Netherlands are usually related to farmers' risk aversion combined with the need to dispose large amounts of manure, however alternatives for manure processing and/or export will likely require complex changes along the supply chain. Rotations with legumes and greater use of compost may reduce $\mathrm{EIA}_{\mathrm{Ha}}$ and $\mathrm{EIA}_{\mathrm{DM}}$ by rendering farming systems more efficient (Bos et al., 2017), but can be associated with greater $\mathrm{N}_{2} \mathrm{O}$ and $\mathrm{CO}_{2}$ emissions at crop level (Bos et al., 2017) and are not always easy to adopt at large scale.

Dutch farming is already land-constrained (e.g. no expansion possible), intensely managed (e.g. many cows per unit land) and highly efficient (e.g. low emissions per unit product) for some commodities. Thus, the reduction of GHG emissions in agriculture should be primarily achieved on a land basis (through lower production volumes) rather than a product basis (through increased efficiency).

\section{Discussion}

Our results highlight the interdependence of regional EIA trajectories to achieve global SDG targets. The necessary EIA reduction in Western Europe and consequently in the Netherlands is a function of the EIA reduction achieved elsewhere. This accentuates the need for concerted action amongst regions and countries, as well as level playing field in terms of market regulations and production standards.

The need to cut down the GHG emission intensity of agriculture per land unit $\left(\mathrm{EIA}_{\mathrm{Ha}}\right)$ is relatively small at global level and large for WEU and the Netherlands. For EIA $_{\mathrm{DM}}$ the reduction from WEU and the Netherlands is less than that achieved at a global level. Although most mitigation should happen in the developing world in terms of EIA $\mathrm{DM}_{\mathrm{DM}}$, most of the effort to reduce $\mathrm{EIA}_{\mathrm{Ha}}$ and absolute GHG emissions must be undertaken by developed countries. This mainly reflects the projected need to increase agricultural production in developing countries. At the country level, the need for stricter GHG reduction targets is exacerbated by the high GDP per capita of the Netherlands, used as a reference for downscaling method 3 .

\subsection{Existing policy targets vs. model projections}

According to existing European and Dutch climate policies, agriculture will play a major role in GHG emission reduction in the coming decades. The 2030 European Framework for Climate and Energy includes EU-wide targets and policy objectives for 2020-2030 (EUCommission, 2014), including a 40\% cut in GHGs compared to 1990 levels, to be met through emission cuts of $43 \%$ in sectors covered by the EU emissions trading system (ETS) and 30\% in non-ETS sectors such as agriculture (all relative to 2005 emission levels).

The European Commission has also proposed a Roadmap for moving to a competitive low carbon economy by 2050 , reflecting a longer-term commitment to stricter climate mitigation targets (i.e. a rise in mean global temperature below $2{ }^{\circ} \mathrm{C}$ ) (EU-Commission, 2016). Milestones include a $60 \%$ emission cut by 2040 and an $80 \%$ emission cut by 2050 (including all GHG sources). Such a pathway implies annual reductions of roughly $1 \%$ in $2010-2020,1.5 \%$ in $2020-2030$, and $2 \%$ in 2030-2050. According to the Commission's projections, agriculture alone can reduce non- $\mathrm{CO}_{2}$ emissions by $42-49 \%$ compared to 1990 , which is in line with IMAGE projections (Table 2).

It should be mentioned that the EU Agricultural Outlook (Capros et al., 2013) expects a higher yield growth than that projected by IMAGE and somewhat constant non- $\mathrm{CO}_{2}$ emissions in agriculture till 2050 (while IMAGE projects them to fall by $41-56 \%$, in line with the European Commission 2050 Roadmap (EU-Commission, 2016)).

In recent years, several member-states have been voluntarily adopting stricter climate targets and advocating for deeper emission cuts for the European Union. In the Netherlands, a new climate agreement has been reached recently, according to which total GHG emissions must be $95 \%$ lower than in 1990 by 2050. A subsequent target proposed for agriculture (3.5 Mton of $\mathrm{CO}_{2} \mathrm{eq}$ by 2030 (Klimaatakkord, 2018)) reinforces the need for joint efforts from all sectors of the economy, especially since adopted and proposed policies in the EU and the Netherlands have been shown insufficient to meet the Paris Agreement's climate objectives by 2030 (Van Vuuren et al., 2017a).

\subsection{Historical vs. projected EIA trends in Dutch agriculture}

Our results point at the need to reduce agricultural methane emissions by $34-52 \%$ in Dutch agriculture. However, the persistence of past EIA trends is uncertain and would be far below the level of EIA reduction modelled as necessary to achieve climate change mitigation targets (Table 3), implying that stronger mitigation action is needed.

Multiple technologies could help reduce GHG emissions from enteric fermentation, manure management and agricultural soils. These technologies might become cheaper as a result of innovation, adoption and diffusion, while new mitigation options might emerge once high taxes are levied on GHG emissions. Yet, trade-offs and non-technical barriers such as high costs and technical complexity may hamper their adoption and overall contribution to climate change mitigation.

In IMAGE, the price of mitigation action is reflected in a global carbon tax levied on different activities given their GHG emission levels. Until 2020, the carbon tax in our projections is almost the same under all scenarios but varies a lot until 2030 (the timeframe of the SDGs) and even more so until 2050. The variation across scenarios arises from the different climate targets $\left(1.5^{\circ} \mathrm{C}\right.$ and $\left.2^{\circ} \mathrm{C}\right)$ and the ability

\section{Table 3}

Annual reductions in Dutch EIA $\mathrm{DM}_{\mathrm{DM}}$ and $\mathrm{EIA}_{\mathrm{Ha}}$ according to IMAGE future projections (top) and observed annual reduction in the period 1990-2015 for dairy and crop production. Positive numbers indicate a decrease whereas negative numbers indicate an increase. Ranges indicate results of different downscaling methods.

\begin{tabular}{clll}
\hline & & $\begin{array}{l}\text { Annual EIA } \\
\text { reduction (\%) }\end{array}$ & $\begin{array}{l}\text { Annual EIA } \\
\text { reduction (\%) }\end{array}$ \\
\hline Modelled (2015- & SSP1-1.5C & $1.97-2.37$ & $1.11-1.43$ \\
2050) & SSP1-2C & $1.65-1.96$ & $0.91-1.24$ \\
& SSP2-1.5C & $2.21-2.42$ & $1.04-1.41$ \\
Observed (1990- & SSP2-2C & $1.65-1.84$ & $0.78-1.13$ \\
2015) & $\begin{array}{l}\text { Historic annual } \\
\text { change }\end{array}$ & 0.91 & -0.02 \\
\hline
\end{tabular}


to adopt mitigation measures under each storyline (SSP1 and SSP2). The gradual increase in carbon taxes indicates that both the lowhanging fruits for mitigation (mostly available for developing countries) as well as more costly mitigation options (i.e. of higher marginal abatement cost) will be required.

At low carbon taxes, the Netherlands will not be able to achieve much additional mitigation, implying that most of the GHG emission reduction would come at a high marginal cost. It is therefore risky to solely rely on existing technologies to achieve climate change mitigation. The fact that mitigation under SSP1 (with greater dietary changes) is cheaper and more easily attainable is a clear argument in favour of more systemic, behavioural changes.

\subsection{Changes in production and consumption patterns}

Besides technological fixes and incremental changes, transformative agricultural pathways involving greater circularity and behavioural change are paramount. The tighter coupling of plant and livestock production (or agriculture and other sectors), focused on systems integration rather than the linear optimisation of specific processes or products, could help lower GHG emissions (Jurgilevich et al., 2016; Scholten et al., 2018). Changes in absolute production volumes and more sustainable consumption patterns are a necessary complement.

Herd reduction deserves to be highlighted in this context. Although the Dutch government has indicated that technical measures are preferred over herd reduction to reduce GHG emissions (Klimaatakkord, 2018), IMAGE projections reveal that most of the mitigation should be achieved through the reduction of methane emissions (Table 1), which are also the main GHG in Dutch agriculture. Besides, herd reduction is relevant to all three processes analysed in this paper, as it helps reduce methane emissions from enteric fermentation and manure management while also reducing nitrous oxide emissions related to feed cultivation and manure disposal. Finally, almost $100 \%$ of concentrates used in dairy, pig and poultry feed in Dutch farming are imported from countries with high environmental footprints (CBS, 2016).

Given the interdependence amongst different world regions and countries, changes in the Dutch agricultural sector may affect production levels elsewhere. Unless accompanied by changes in dietary patterns, the reduction of the Dutch herd might lead to the mere reallocation of production to another, less GHG-efficient world region. In other words, if the demand for meat and dairy remains the same, a reduction in the Dutch production would have to be compensated by an increase in the supply of these products elsewhere (possibly where livestock production is associated with even higher GHG emissions). To prevent production cuts to have such a perverse effect on global GHG emissions, it is important that reduction in production is driven by reduced consumption.

Current global demand for livestock products stands at $38 \mathrm{~kg} / \mathrm{ca}-$ pita/year on average, whereas in WEU it is more than double that amount (i.e. $87 \mathrm{~kg} /$ capita/year). Different types of livestock products show different dynamics at each scale (Fig. S7). By 2050, global percapita demand is projected to rise for all livestock products but milk, reaching $40 \mathrm{~kg} /$ capita/year under SSP1 and $42 \mathrm{~kg} /$ capita/year under SPP2 due to higher welfare levels in Asia, Africa and Latin America. The limited increase in milk is related to the large population growth in Asia and Sub-Saharan Africa, where dairy consumption is lower than in Europe and North America. In WEU, under SSP1, the demand for livestock products is projected to decrease (i.e. $69 \mathrm{~kg} / \mathrm{capita} /$ year) due to changing diets and reduced food waste. Under SSP2, it remains relatively constant, with consumption of non-ruminant products increasing due to higher welfare levels. In WEU, in SSP2, the historical relationship between rising income and meat consumption persists, while in SSP1 rising income is associated with a lower rate of increase of meat consumption. Changes in dietary patterns would have to be additional to what is already considered in either of these scenarios.
It is important to note that the projected consumption of different food products covers a range of possibilities. These may differ from historic trends due to varying assumptions on future diets and how rising incomes affect dietary choices in each region. In our analysis, projections were calibrated according to Alexandratos and Bruinsma (2012), and diverge from recent historic trends. This is particularly evident with regards to global beef consumption, which has witnessed a slight decrease since 1990 while our projections show it to increase across all scenarios. Similarly, our projections for global milk and pork consumption are lower than recent trends. The uncertainty concerning the future production of ruminants and monogastrics is important given the GHG emissions of each group. This affects baseline emissions and, ultimately, the level of effort needed to achieve the overall EIA reduction consistent with the Paris climate targets.

It should also be noted that agricultural activities have important links with other GHG emission sources included in IAM simulations but not explicitly mentioned in our discussion of climate change mitigation options. At global level, these include industry (due to the production of fertilizers and other inputs) and on-farm energy use (due to field operations). In the Netherlands, the emissions from land use (mainly related to past conversion of peatland to grass (Van den Akker et al., 2010)) and the large reliance on energy-intensive greenhouses for horticultural production (Vermeulen et al., 2010) are also relevant. Changes in absolute production volumes and more sustainable consumption patterns would lead to important synergies concerning these indirect GHG emissions.

\subsection{Model and scenario uncertainties}

Any modelling assessment has significant uncertainties arising from the structure and parameterization of the model. These include assumptions concerning future behavioural choices, total agricultural demand, technological change (including yield-input relationships), etc. As simplified representations of the real world, models contain a stylized version of specific processes and their interrelationships. Consumer choices are based on product prices and possible substitution between them, according to elasticities.

The above leads to an epistemological uncertainty which, though irreducible, can be better understood through scenario analyses and inter-model comparisons. To explore uncertainty, we have adopted two different storylines (SSP1 \& SSP2) spanning a range of possible futures. As such, these storylines are not meant to be exact predictions of futures we should/could aspire to, but rather highlight how different potential futures affect our results. As mentioned in Section 2.1.3, inter-model comparisons using harmonized scenarios have shown IMAGE to be aligned with emission projections from other IAMs.

Some limitations of the analysis presented here must be considered. Being a rational economic model with climate constrained productivity, IMAGE does not adequately represent, for example, the potential collapse of production systems due to loss of biodiversity (Díaz et al., 2015). It also fails to account for political, economic or climatic shocks which may affect food production and scenario storylines. Finally, several doubts exist concerning the real-world implementation of the scenario storylines and the governance structures needed to ensure them.

The level of change implied in SSP1 will likely be difficult to achieve, as it touches upon complex and interlinked issues such as population growth, trade restrictions, land use, technological development and spillover, dietary changes, food waste, etc. Though the conditions enabling such changes are context-specific, a mix of positive incentives and stricter regulations aided by public campaigns to raise awareness about the urgency of the matter might be the shortest route to improvement. While highlighting the importance of behavioural change and individual choices in places like the Netherlands, our results underscore the need for coordinated action at national and regional levels - particularly to ensure a level playing field in terms of 
production standards.

\section{Conclusion}

The agricultural sector is crucial for achieving climate change mitigation targets, especially in the long term, and offers an opportunity to enhance sustainable food production on several fronts besides GHG emissions. By contrasting IAM projections and expert assessment in a concrete case study, we show that the level of mitigation calculated through aggregate models cannot be easily translated into real-world technologies. The example of the Netherlands highlights the difficulties and trade-offs faced by high-intensity countries as they try to decarbonise their food production systems. Besides, high-tech strategies that could achieve EIA reduction may not ensure social, economic or environmental sustainability, thus rendering more systemic solutions necessary.

Per-product metrics (e.g. EIA) should be investigated in combination with absolute production volumes and associated GHG emissions. Recent attempts to quantify the optimal level of animal protein consumption from a resource use efficiency perspective clearly show the need to reduce the consumption of meat and dairy at the global level (Van Zanten et al., 2018). By accounting for trade flows across regions, our study supports the conclusion that the reduction of meat consumption implied in the SSP1 storyline should be even greater in Western Europe and other regions.

Our projections indicate the maximum EIA values consistent with the achievement of climate change mitigation targets. Still, countries should strive for lower levels of EIA given the uncertainties inherent to modelling simulations and to the ability of other countries to achieve their own targets in the future. The lower level of $\mathrm{EIA}_{\mathrm{DM}}$ reduction needed in Western Europe relative to most other regions may mask the fact that Western Europe consumes products from regions with a high environmental footprint, such as concentrates for animal feed. In addition to reducing emissions domestically, rich economies can contribute to climate change mitigation globally through international mitigation financing and changes in consumption and import patterns.

Future research should explore the points highlighted above, as well as parametric uncertainty, product-specific nutritional values, storylines based on different trade scenarios, a more comprehensive analysis of GHG emissions that considers emissions related to e.g. feed production or other farm processes, and a more circular economy. The calculation of country-specific marginal cost curves for GHG emission abatement is another important research avenue for a robust quantitative assessment of the feasibility of EIA reduction targets as projected by aggregate models. The same is true for quantifying the effects of the reallocation of livestock production from the Netherlands to a less GHGefficient country, in a scenario where only Dutch production - but not consumption - falls. Finally, studies that assess the feasibility of downscaled projections are, by bringing together bottom-up and topdown research, essential for effective policy design and should be further encouraged.

\section{Acknowledgements}

This study was developed in the context of the research project Targets for Sustainable and Resilient Agriculture - TSARA, funded by the EU Joint Programming Initiative under the FACCE SURPLUS call (project no. 3183600230).

\section{Supplementary materials}

Supplementary material associated with this article can be found, in the online version, at doi:10.1016/j.gloenvcha.2019.101983.

\section{References}

Abel, G.J., Barakat, B., Samir, K., Lutz, W., 2016. Meeting the Sustainable Development Goals leads to lower world population growth. Proc. Natl. Acad. Sci. U.S.A. 113, 14294-14299.

Alexandratos, N., Bruinsma, J., 2012. World agriculture towards 2030/2050: the 2012 revision. ESA Working Paper. Rome, FAO.

Allen, M., Dube, P., Solecki, W., Aragon-durand, F., Cramer, W., Humphreys, S., Kainuma, M., Kala, J., Mahowald, N., Mulugetta, J., Perez, R., Wairiu, M., 2018. Special Report on Global Warming of $1.5^{\circ} \mathrm{C}$ (SR15). Intergovernmental Panel on Climate Change, New York.

Bauer, N., Rose, S.K., Fujimori, S., van Vuuren, D.P., Weyant, J., Wise, M., Cui, Y., Daioglou, V., Gidden, M.J., Kato, E., 2018. Global energy sector emission reductions and bioenergy use: overview of the bioenergy demand phase of the EMF-33 model comparison. Climatic Change 1-16.

Bondeau, A., Smith, P.C., Zaehle, S., Schaphoff, S., Lucht, W., Cramer, W., Gerten, D., Lotze-Campen, H., Müller, C., Reichstein, M.J.G.C.B., 2007. Modelling the role of agriculture for the 20th century global terrestrial carbon balance. Global Change Biol. 13, 679-706.

Bos, J.F., ten Berge, H.F., Verhagen, J., van Ittersum, M.K., 2017. Trade-offs in soil fertility management on arable farms. Agric. Syst. 157, 292-302.

Bouwman, A., van der Hoek, K., Eickhout, B., Soenario, I., 2005. Exploring changes in world ruminant production systems. Agric. Syst. 84, 121-153.

Britz, W., 2003. Major enhancements of @ 2030 modelling system. Bonn. http://www. agp.unibonn.de/agpo/rsrch/at2030/@2030_2003.doc (accessed 25/11/2004).

Capros, P., de Vita, A., Tasios, N., Papadopoulos, D., Siskos, P., Apostolaki, E., Zampara, M., Paroussos, L., Fragiadakis, K., Kouvaritakis, N., 2013. EU Energy, Transport and GHG Emissions: Trends to 2050, Reference Scenario 2013. EU-Commission, Technical University of Athens, IIASA \& EuroCARE GmbH.

CBS, 2016. The Internationalisation Monitor 2016 II - Agribusiness. Statistics Netherlands, The Hague/Heerlen/Bonaire.

CBS. 2018. Statistics Netherlands[Online]. Available:https://www.cbs.nl/en-gb/ economy/agriculture(accessed 06.2018).

Clarke, L., Jiang, K., Akimoto, K., Babiker, M., Blanford, G., Fisher-Vanden, K., Hourcade, J.-C., Krey, V., Kriegler, E., Löschel, A., 2014. Assessing transformation pathways. Climate Change 2014: Mitigation of Climate Change. IPCC Working Group III Contribution to AR5. Cambridge University Press.

Coenen, P.W.H.G., van der Maas, C.W.M., Zijlema, P.J., Arets, E.J.M.M., Baas, K., van den Berghe, A.C.W.M., van Huis, E.P., Geilenkirchen, G., Hoogsteen, M., Spijker, J., te Molder, R., Dröge, R., Montfoort, J.A., Peek, C.J., Vonk, J.S., et al., 2017. Greenhouse Gas Emissions in the Netherlands 1990-2015 - National Inventory Report 2017. National Institute for Public Health and the Environment (RIVM), Bilthoven, Netherlands RIVM Report 2017-0033.

Daioglou, V., Doelman, J.C., Wicke, B., Faaij, A., van Vuuren, D.P., 2019. Integrated assessment of biomass supply and demand in climate change mitigation scenarios. Global Environ. Change 54, 88-101.

de Haas, Y., Pszczola, M., Soyeurt, H., Wall, E., Lassen, J., 2017. Invited review: phenotypes to genetically reduce greenhouse gas emissions in dairying. J. Dairy Sci. 100, 855-870.

de Vries, J., Vinken, T., Hamelin, L., de Boer, I., 2012. Comparing environmental con sequences of anaerobic mono-and co-digestion of pig manure to produce bio-energy - a life cycle perspective. Bioresource Technol. 125, 239-248.

den Elzen, M.G., Lucas, P.L., van Vuuren, D.P., 2008. Regional abatement action and costs under allocation schemes for emission allowances for achieving low $\mathrm{CO}_{2}$-equivalent concentrations. Climatic Change 90, 243-268.

Díaz, S., Demissew, S., Carabias, J., Joly, C., Lonsdale, M., Ash, N., Larigauderie, A., Adhikari, J.R., Arico, S., Báldi, A., Bartuska, A., 2015. The IPBES Conceptual Framework-connecting nature and people. Curr. Opin. Environ. Sustain. 14, 1-16.

Doelman, J.C., Stehfest, E., Tabeau, A., van Meijl, H., Lassaletta, L., Gernaat, D.E. Hermans, K., Harmsen, M., Daioglou, V., Biemans, H., 2018. Exploring SSP land-use dynamics using the IMAGE model: regional and gridded scenarios of land-use change and land-based climate change mitigation. Global Environ. Change 48, 119-135.

Ebi, K.L., Hallegatte, S., Kram, T., Arnell, N.W., Carter, T.R., Edmonds, J., Kriegler, E., Mathur, R., O'Neill, B.C., Riahi, K., 2014. A new scenario framework for climate change research: background, process, and future directions. Climatic Change 122, 363-372.

Eu-Commission, 2009. Decision No. 406/2009/EC of the European Parliament and of the Council of 23 April 2009 on the effort of member states to reduce their greenhouse gas emissions to meet the community's greenhouse gas emission reduction commitments up to 2020. Off. J. Eur. Union L140, 136-148.

Eu-Commission, 2014. A policy framework for climate and energy in the period from 2020 to 2030 - Communication from the Commission to the European Parliament, the Council, the European Economic and Social Committee and the Committee of the Regions. COM 15 final. Brussels.

Eu-Commission, 2016. A European Agenda for the collaborative economy Communication from the Commission to the European Parliament, the Council, the European Economic and Social Committee and the Committee of the Regions. COM 356 final. Brussels.

FAOSTAT, 2017. Main Database. Food and Agriculture Organization of the United Nations, Rome, Italy Available at: http://www.fao.org/faostat/en/\#data (accessed 06.2017).

Gerber, P., Hristov, A., Henderson, B., Makkar, H., Oh, J., Lee, C., Meinen, R., Montes, F., Ott, T., Firkins, J., 2013. Technical options for the mitigation of direct methane and nitrous oxide emissions from livestock: a review. Animal 7, 220-234.

Gernaat, D.E., Calvin, K., Lucas, P.L., Luderer, G., Otto, S.A., Rao, S., Strefler, J., van 
Vuuren, D.P., 2015. Understanding the contribution of non-carbon dioxide gases in deep mitigation scenarios. Global Environ. Change 33, 142-153.

Godfray, H.C.J., Beddington, J.R., Crute, I.R., Haddad, L., Lawrence, D., Muir, J.F., Pretty, J., Robinson, S., Thomas, S.M., Toulmin, C., 2010. Food security: the challenge of feeding 9 billion people. Science 327, 812-818.

Helming, J., Jansen, S., van meijl, H., Tabeau, A., 2010. European Farming and Post-2013 CAP Measures: A Quantitative Impact Assessment Study (No. 2103). LEI, Wageningen UR, The Netherlands.

Hertel, T.W., 1997. Global Trade Analysis: Modeling and Applications. Cambridge university press.

Hristov, A., Oh, J., Firkins, J., Dijkstra, J., Kebreab, E., Waghorn, G., Makkar, H., Adesogan, A., Yang, W., Lee, C., 2013. Mitigation of methane and nitrous oxide emissions from animal operations. I. A review of enteric methane mitigation options. J. Anim. Sci. 91, 5045-5069.

IEA, 1970. World Energy Balances. OECD, Paris, France Available at: http://www.iea. $\mathrm{org} /$ statistics/topics/energybalances/ (accessed 11.2018).

Iiasa, F., 2012. Global Agro-ecological Zones-Model Documentation (GAEZ v. 3.0) International Institute of Applied Systems Analysis \& Food and Agricultural Organization, Laxenburg, Austria \& Rome, Italy.

JRC2011. Emission Database for Global Atmospheric Research - v. 4.2. Nov 2011 ed. Available at:http://edgar.jrc.ec.europa.eu/overview.php?v=42(accessed 11.2018).

Jurgilevich, A., Birge, T., Kentala-Lehtonen, J., Korhonen-Kurki, K., Pietikäinen, J., Saikku, L., Schösler, H., 2016. Transition towards circular economy in the food system. Sustainability 8, 69.

Kanter, D.R., Schwoob, M.-H., Baethgen, W.E., Bervejillo, J.E., Carriquiry, M., Dobermann, A., Ferraro, B., Lanfranco, B., Mondelli, M., Penengo, C., 2016. Translating the Sustainable Development Goals into action: a participatory backcasting approach for developing national agricultural transformation pathways. Global Food Secur. 10, 71-79.

Kindermann, G., Obersteiner, M., Sohngen, B., Sathaye, J., Andrasko, K., Rametsteiner, E., Schlamadinger, B., Wunder, S., Beach, R., 2008. Global cost estimates of reducing carbon emissions through avoided deforestation. Proc. Natl. Acad. Sci. U.S.A. 105, 10302-10307.

Klein Goldewijk, K., Beusen, A., Janssen, P., 2010. Long-term dynamic modeling of global population and built-up area in a spatially explicit way: HYDE 3.1. The Holocene 20, 565-573.

Klimaatakkord. 2018. Sectortafel Landbouw en Landgebruik. Contribution from the Agriculture and Land Use Sector Table to the Proposal for the Main Lines of the Climate Agreement. The Hague, The Netherlands.

Kool, A., Hilhorst, G., van der Vegte, D., 2005. Realisatie van mestvergisting op De Marke: onderzoek en demonstratie - Report 50. Wageningen Livestock Research \& CLM Research and Advice, The Netherlands.

Lampe, M., Willenbockel, D., Ahammad, H., Blanc, E., Cai, Y., Calvin, K., Fujimori, S., Hasegawa, T., Havlik, P., Heyhoe, E., 2014. Why do global long-term scenarios for agriculture differ? An overview of the AgMIP global economic model intercomparison. Agric. Econ. 45, 3-20.

Lassaletta, L., Billen, G., Grizzetti, B., Anglade, J., Garnier, J., 2014. 50 year trends in nitrogen use efficiency of world cropping systems: the relationship between yield and nitrogen input to cropland. Environ. Res. Lett. 9, 105011.

Lee, C., Beauchemin, K.A., 2014. A review of feeding supplementary nitrate to ruminant animals: nitrate toxicity, methane emissions, and production performance. Can. J, Anim. Sci. 94, 557-570.

Machado, L., Tomkins, N., Magnusson, M., Midgley, D.J., de Nys, R., Rosewarne, C.P., 2018. In vitro response of rumen microbiota to the antimethanogenic red macroalga Asparagopsis taxiformis. Microb. Ecol. 75, 811-818.

Mandryk, M., Doelman, J., Stehfest, E., 2015. Assessment of Global Land Availability: Land Supply for Agriculture. LEI, Wageningen UR. The Netherlands No. 7.

Montes, F., Meinen, R., Dell, C., Rotz, A., Hristov, A., Oh, J., Waghorn, G., Gerber, P., Henderson, B., Makkar, H., 2013. Special topics-mitigation of methane and nitrous oxide emissions from animal operations. II. A review of manure management mitigation options 1. J. Anim. Sci. 91, 5070-5094.

Mostert, P., Bokkers, E., van Middelaar, C., Hogeveen, H., de Boer, I., 2018. Estimating the economic impact of subclinical ketosis in dairy cattle using a dynamic stochastic simulation model. Animal 12, 145-154.

Nelson, A., 2008. Estimated Travel Time to the Nearest City of 50,000 or More People in Year 2000. Global Environment Monitoring Unit-Joint Research Centre of the European Commission, Ispra Italy URL: http://bioval.jrc.ec.europa.eu/products/ gam/ (accessed 30.07.2011)

Nelson, G.C., Valin, H., Sands, R.D., Havlík, P., Ahammad, H., Deryng, D., Elliott, J., Fujimori, S., Hasegawa, T., Heyhoe, E., 2014. Climate change effects on agriculture: economic responses to biophysical shocks. Proc. Natl. Acad. Sci. U.S.A. 111, 3274-3279.

Nilsson, M., Griggs, D., Visbeck, M., 2016. Policy: map the interactions between Sustainable Development Goals. Nat. News 534, 320.

O'Neill, B.C., Kriegler, E., Riahi, K., Ebi, K.L., Hallegatte, S., Carter, T.R., Mathur, R., van Vuuren, D.P., 2014. A new scenario framework for climate change research: the concept of shared socioeconomic pathways. Climatic Change 122, 387-400.

Obersteiner, M., Walsh, B., Frank, S., Havlík, P., Cantele, M., Liu, J., Palazzo, A., Herrero, M., Lu, Y., Mosnier, A., 2016. Assessing the land resource-food price nexus of the Sustainable Development Goals. Sci. Adv. 2, e1501499.

Olijhoek, D., Løvendahl, P., Lassen, J., Hellwing, A., Höglund, J., Weisbjerg, M., Noel, S., Mclean, F., Højberg, O., Lund, P., 2018. Methane production, rumen fermentation, and diet digestibility of Holstein and Jersey dairy cows being divergent in residual feed intake and fed at 2 forage-to-concentrate ratios. J. Dairy Sci. 101, 9926-9940.

Overmars, K.P., Stehfest, E., Tabeau, A., van Meijl, H., Beltrán, A.M., Kram, T., 2014. Estimating the opportunity costs of reducing carbon dioxide emissions via avoided deforestation, using integrated assessment modelling. Land Use Policy 41, 45-60.

Palazzo, A., Vervoort, J.M., Mason-D'croz, D., Rutting, L., Havlík, P., Islam, S., Bayala, J. Valin, H., Kadi, H.A.K., Thornton, P.J.G.E.C., 2017. Linking regional stakeholder scenarios and shared socioeconomic pathways: quantified west African food and climate futures in a global context. Global Environ. Change 45, 227-242.

Popp, A., Calvin, K., Fujimori, S., Havlik, P., Humpenöder, F., Stehfest, E., Bodirsky, B.L., Dietrich, J.P., Doelmann, J.C., Gusti, M., 2017. Land-use futures in the shared socioeconomic pathways. Global Environ. Change 42, 331-345.

Pradhan, P., Costa, L., Rybski, D., Lucht, W., Kropp, J.P., 2017. A systematic study of Sustainable Development Goal (SDG) interactions. Earth's Future 5 (11), 1169-1179.

Prins, H., Daatselaar, C., de Koeijer, T., 2017. Bemesting en bodemoverschotten van stikstof en fosfaat 1991-2014. Wageningen Economic Research, The Netherlands.

Rao, S., Klimont, Z., Leitao, J., Riahi, K., van Dingenen, R., Reis, L.A., Calvin, K., Dentener, F., Drouet, L., Fujimori, S., 2016. A multi-model assessment of the cobenefits of climate mitigation for global air quality. Environ. Res. Lett. 11, 124013.

Reijneveld, A., van Wensem, J., Oenema, O., 2009. Soil organic carbon contents of agricultural land in the Netherlands between 1984 and 2004. Geoderma 152 231-238.

Riahi, K., van Vuuren, D.P., Kriegler, E., Edmonds, J., O'Neill, B.C., Fujimori, S., Bauer, N., Calvin, K., Dellink, R., Fricko, O, 2017. The shared socioeconomic pathways and their energy, land use, and greenhouse gas emissions implications: an overview. Global Environ. Change 42, 153-168.

Rockström, J., Steffen, W., Noone, K., Persson, Å., Chapin, F.S., Lambin, E.F., Lenton, T.M., Scheffer, M., Folke, C., Schellnhuber, H.J., 2009. A safe operating space for humanity. Nature 461, 472-475.

Rose, S.K., Kriegler, E., Bibas, R., Calvin, K., Popp, A., van Vuuren, D.P., Weyant, J., 2014 Bioenergy in energy transformation and climate management. Climatic Change 123, 477-493.

Schleussner, C.-F., Deryng, D., Müller, C., Elliott, J., Saeed, F., Folberth, C., Liu, W., Wang, X., Pugh, T.A., Thiery, W., 2018. Crop productivity changes in $1.5{ }^{\circ} \mathrm{C}$ and $2{ }^{\circ} \mathrm{C}$ worlds under climate sensitivity uncertainty. Environ. Res. Lett. 13, 064007.

Scholten, M., Bianchi, F., de Boer, I., Conijn, J., Dijkstra, J., van Doorn, A., van den Ende, J., Fresco, L., Jongschaap, R., van Kernebeek, H., 2018. Technische Briefing Kringlooplandbouw; Notitie opgesteld op verzoek van de Tweede Kamer Commissie LNV: Wat mogen we verwachten van een circulaire voedselproductie gebaseerd op een kringlooplandbouw. het perspectief van klimaat-en biodiversiteitdoelen? Wageningen University and Research.

Schröder, J., Neeteson, J., 2008. Nutrient management regulations in The Netherlands. Geoderma 144, 418-425.

Silva, J.V., Reidsma, P., van Ittersum, M.K., 2017. Yield gaps in Dutch arable farming systems: analysis at crop and crop rotation level. Agric. Syst. 158, 78-92.

Smith, P., Nayak, D., Linthorst, G., Peters, D., Bucquet, C., van Vuuren, D., Stehfest, E., Harmsen, M., van den Brink, L., 2016. Science-based GHG Emissions Targets for Agriculture and Forestry Commodities - Final report to the KR Foundation. Universty of Aberdeen, Ecofys \& PBL.

Stehfest, E., van Vuuren, D., Bouwman, L., Kram, T., 2014. Integrated Assessment of Global Environmental Change with IMAGE 3.0: Model Description and Policy Applications. Netherlands Environmental Assessment Agency (PBL).

Stocker, T.F., Qin, D., Plattner, G., Tignor, M., Allen, S., Boschung, J., Nauels, A., Xia, Y., Bex, V., Midgley, P., 2013. Climate Change 2013: The Physical Science Basis. Intergovernmental Panel on Climate Change, Working Group I - Contribution to the IPCC Fifth Assessment Report (AR5).

Tenreiro, T., 2017. Water and Nutrient Use Efficiency of Ware Potato and Winter Wheat Cropping Systems in the Netherlands - A Benchmarking Analysis of Dutch Arable Farming. M.Sc. thesis. Plant Production Systems \& Crop Systems Analysis, Wageningen University.

Un, G. A.2015. Transforming our world: the 2030 agenda for sustainable development. A/ RES/70/1, 21 October.

van Asselt, B., Hjort-Gregersen, K., Møller, H., Sommer, S., Birkmose, T., Nielsen, L.H., 2007. PROBIOGAS. Final Assessment Report. Assessment of a centralised co-digestion plant hypothetically sited in Noord-Brabant region.

van den Akker, J., Kuikman, P., de Vries, F., Hoving, I., Pleijter, M., Hendriks, R., Wolleswinkel, R., Simões, R., Kwakernaak, C., 2010. Emission of $\mathrm{CO}_{2}$ from agri cultural peat soils in the Netherlands and ways to limit this emission. Proceedings of the 13th International Peat Congress After Wise Use-The Future of Peatlands, Vol. 1. Oral Presentations, Tullamore, Ireland. pp. 645-648 8-13 June 2008.

van der Hoek, K., van Schijndel, M., 2006. Background Document on the Calculation Method for the Dutch National Inventory Report. RIVM Report. 680125002.

van Grinsven, H., Bleeker, A., van der Sluis, S., van Schijndel, M., van Dam, J., Tiktak, A., van Gaalen, F., den Uyl, R., Kruitwagen, S., Beck, J., 2017. Evaluatie Meststoffenwet 2016: syntheserapport. Dutch Environmental Assessment Agency (PBL).

van Meijl, H., Havlik, P., Lotze-Campen, H., Stehfest, E., Witzke, P., Domínguez, I.P., Bodirsky, B.L., van Dijk, M., Doelman, J., Fellmann, T., 2018. Comparing impacts of climate change and mitigation on global agriculture by 2050. Environ. Res. Lett. 13, 064021.

van Meijl, H., van Rheenen, T., Tabeau, A., Eickhout, B., 2006. The impact of different policy environments on agricultural land use in Europe. Agric. Ecosys. Environ. 114, 21-38.

van Middelaar, C., Berentsen, P., Dijkstra, J., de Boer, I., 2013. Evaluation of a feeding strategy to reduce greenhouse gas emissions from dairy farming: the level of analysis matters. Agric. Syst. 121, 9-22.

van Middelaar, C., Dijkstra, J., Berentsen, P., de Boer, I., 2014. Cost-effectiveness of feeding strategies to reduce greenhouse gas emissions from dairy farming. J. Dairy Sci. 97, 2427-2439.

van Vuuren, D.P., Boot, P.A., Ros, J., Hof, A.F., den Elzen, M.G., 2017a. The Implications of the Paris Climate Agreement for the Dutch Climate Policy Objectives. Netherlands 
Environmental Assessment Agency, The Hague.

van Vuuren, D.P., Edmonds, J., Kainuma, M., Riahi, K., Thomson, A., Hibbard, K., Hurtt, G.C., Kram, T., Krey, V., Lamarque, J.-F., 2011. The representative concentration pathways: an overview. Climatic Change 109 (5).

van Vuuren, D.P., Kok, M., Lucas, P.L., Prins, A.G., Alkemade, R., van den Berg, M., Bouwman, L., van der Esch, S., Jeuken, M., Kram, T., 2015. Pathways to achieve a set of ambitious global sustainability objectives by 2050: explorations using the IMAGE integrated assessment model. Technol. Forecast. Soc. Change 98, 303-323.

van Vuuren, D.P., Kriegler, E., O'Neill, B.C., Ebi, K.L., Riahi, K., Carter, T.R., Edmonds, J., Hallegatte, S., Kram, T., Mathur, R., 2014. A new scenario framework for climate change research: scenario matrix architecture. Climatic Change 122, 373-386.

van Vuuren, D.P., Stehfest, E., Gernaat, D.E., Berg, M., Bijl, D.L., Boer, H.S., Daioglou, V., Doelman, J.C., Edelenbosch, O.Y., Harmsen, M., 2018. Alternative pathways to the $1.5^{\circ} \mathrm{C}$ target reduce the need for negative emission technologies. Nat. Climate Change $8,391$.

van Vuuren, D.P., Stehfest, E., Gernaat, D.E., Doelman, J.C., van den Berg, M., Harmsen, M., de Boer, H.S., Bouwman, L.F., Daioglou, V., Edelenbosch, O.Y., 2017b. Energy, land-use and greenhouse gas emissions trajectories under a green growth paradigm. Global Environ. Change 42, 237-250. van Zanten, H.H., Herrero, M., Hal, O.V., Röös, E., Muller, A., Garnett, T., Gerber, P.J., Schader, C., de Boer, I.J., 2018. Defining a land boundary for sustainable livestock consumption. Global Change Boil. 9, 4185-4194.

Velthof, G.L., Losada, J.M., 2011. Calculation of Nitrous Oxide Emission from Agriculture in the Netherlands: Update of Emission Factors and Leaching Fraction (No. 2151) Alterra. Wageningen University, The Netherlands.

Vermeulen, T., van der Linden, A., van Os, E., 2010. Emissions of Plant Protection Products from Glasshouses to Surface Water in The Netherlands. RIVM rapport 607407001.

Vervoort, J.M., Thornton, P.K., Kristjanson, P., Förch, W., Ericksen, P.J., Kok, K., Ingram, J.S., Herrero, M., Palazzo, A., Helfgott, A.E.J.G.E.C., 2014. Challenges to scenarioguided adaptive action on food security under climate change. Global Environ. Change 28, 383-394.

Wollenberg, E., Richards, M., Smith, P., Havlík, P., Obersteiner, M., Tubiello, F.N., Herold, M., Gerber, P., Carter, S., Reisinger, A.J.G.C.B., 2016. Reducing emissions from agriculture to meet the 2 C target. Global Change Biol. 22, 3859-3864.

Woltjer, G.B., Kuiper, M., Kavallari, A., van Meijl, H., Powell, J., Rutten, M., Shutes, L., Tabeau, A., 2014. The MAGNET Model: Module Description (No. 14-57). LEI Wageningen UR. The Netherlands. 